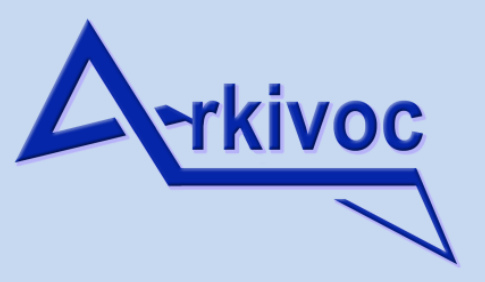

Free to Authors and Readers
A Platinum Open Access Journal for Organic Chemistry
Paper

Arkivoc 2021, part x, 151-163

\title{
Synthesis of C4-substituted coumarins via Pechmann condensation catalyzed by sulfamic acid. Insights into the reaction mechanism by HRMS analysis
}

\author{
Maiara C. Moraes, ${ }^{\text {a,b }}$ Eder J. Lenardão, ${ }^{c}$ and Thiago Barcellos*a
}

a Laboratório de Biotecnologia de Produtos Naturais e Sintéticos, Universidade de Caxias do Sul, 95070-560, Caxias do Sul, RS, Brazil

${ }^{b}$ Instituto Federal de Ciência e Tecnologia do Rio Grande do Sul, Campus Caxias do Sul, 95043-700, Caxias do Sul, RS, Brazil

' LASOL-CCQFA, Universidade Federal de Pelotas - UFPel, P.O. Box 354, 96010 900, Pelotas, RS, Brazil

Email: thiago.barcellos@ucs.br

Received 09-13-2021

Accepted Manuscript 12-19-2021

Published on line $12-28-2021$

\section{Abstract}

A series of functionalized C4-substituted coumarins were synthesized by exploring the reaction of activated and non-activated phenols and $\beta$-ketoesters under solvent-free conditions in the presence of sulfamic acid as a Brønsted acid catalyst. Fifteen examples were prepared with moderate to excellent yields (50\% to $90 \%$ ) using $10 \mathrm{~mol} \%$ of the catalyst. Furthermore, it was possible from the proposed methodology to scale up the synthesis of coumarins to obtain up to $11 \mathrm{~g}$ of product. This work also provides a preliminary insight into the reaction mechanism using high-resolution mass spectrometry analysis. The key cinnamic acid derivative intermediate was detected, implying that under the evaluated conditions, the mechanistic pathway starts with an aromatic electrophilic substitution followed by dehydration reaction and intramolecular transesterification.

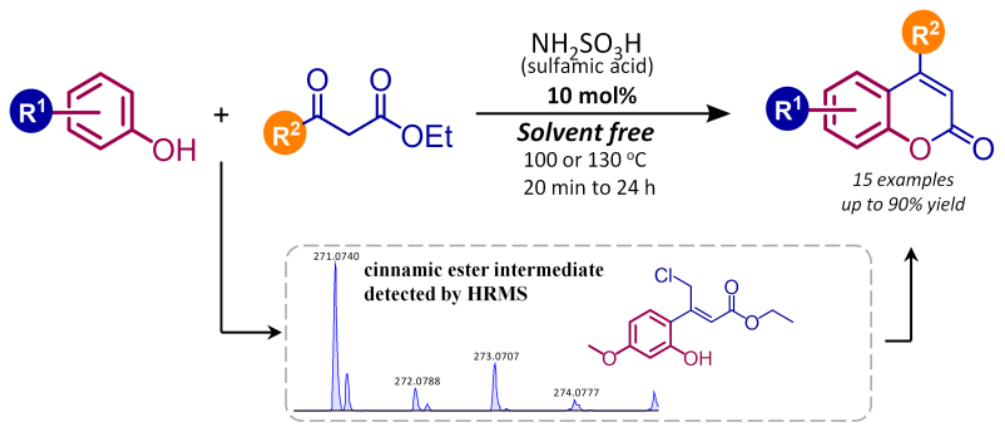

Keywords: Green chemistry, $\alpha$-benzopyrone, acid catalysis, reaction mechanism, HRMS 


\section{Introduction}

Two centuries after its first isolation in 1820, coumarin ( $\alpha$-benzopyrone) still is one of the most explored naturally occurring building blocks. Coumarin and derivatives are common and abundantly found in different parts of higher plants - with the highest concentration in fruits, seeds, roots, and leaves, and also found in fungi and bacteria. ${ }^{1}$ In addition, their synthesis is a subject of great interest to synthetic ${ }^{2}$ and medicinal chemists $^{3,4}$ due to the extensive range of pharmacological activities. These activities include antimicrobial, ${ }^{5}$ antileishmanial, ${ }^{6}$ scavenging of reactive oxygen species (ROS), ${ }^{7}$ anti-inflammatory, anticoagulant, antithrombotic, vasodilatory, ${ }^{8}$ antiviral, ${ }^{9}$ and anticancer. ${ }^{10-12}$ Some examples of coumarin derivatives that have made their way to the clinic include warfarin, novobiocin, and carbochromen (Figure 1). ${ }^{4}$ Besides, members of this group display a broad range of applications, such as fragrances, perfumes, food additives, cosmetics, agrochemicals, and also exhibit unique fluorescence properties that make them useful for several photonic applications. For instance, the Uvitex SWN (Figure 1) is an optical whitening agent used in light-emitting devices. ${ }^{13,14}$

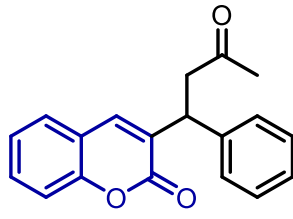

warfarin (anticoagulant)

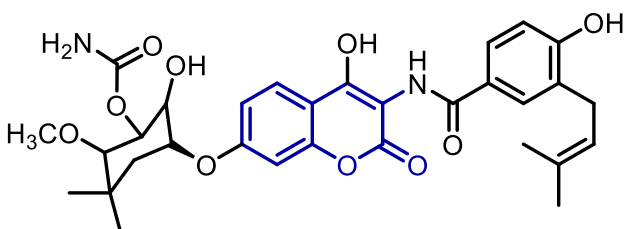

novobiocin

(antibiotic)

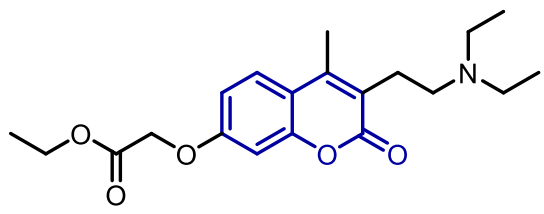

carbochromen (vasodilator)

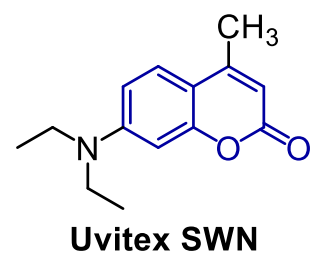

(optical whitening agent)

Figure 1. Examples of compounds of interest containing coumarin in their structure.

Coumarins have been synthesized by several methods, including Pechmann condensation, Perkin, Knoevenagel, Reformatsky, and Wittig reactions. ${ }^{2}$ The Pechmann reaction ${ }^{15}$ is one of the most versatile and straightforward methods to prepare coumarins, which involves the acid-promoted condensation of a phenol with $\beta$-ketoesters, achieving good yields of 4 -substituted coumarins. The progress and course of the reaction depend on the nature of the phenols, the $\beta$-ketoesters, and the catalyst. ${ }^{16}$ Since the seminal work from Pechmann, the use of this superior and practical protocol has been extensively studied, and it has found application as a central strategy for the synthesis of a broad range of coumarin derivatives. ${ }^{2,16}$ Among the modifications and improvements described through the years, a variety of catalytic systems have been successfully employed for this transformation. ${ }^{17-21}$ However, there are still significant limitations that need to be overcome, which include strong acidic conditions, low functional group tolerance, toxic solvents or catalysts, an excessive amount of expensive catalysts, ${ }^{21,22}$ and the difficulty in recovering/reusing the catalyst.

Among the catalysts that have been proposed, sulfamic acid $\left(\mathrm{SA}, \mathrm{NH}_{2} \mathrm{SO}_{3} \mathrm{H}\right)$ has emerged as a suitable Brønsted acid catalyst with the desired characteristic for a large-scale process. SA is a relatively strong zwitterionic inorganic acid, non-hygroscopic, easy to handle, non-corrosive, non-volatile, odorless, and 
commercially available at low cost. ${ }^{23,24}$ These characteristics make sulfamic acid a reliable candidate to promote acid-catalyzed reactions, such as esterification, ${ }^{25}$ Biginelli condensation, ${ }^{26}$ hydrothiolation of terminal alkynes, ${ }^{27}$ and Michael addition. ${ }^{28}$ SA was also previously reported as a suitable catalyst for the Pechmann condensation between activated phenols and non-functionalized $\beta$-ketoesteres. ${ }^{29}$ However, the method was restricted to alkyl- and phenyl-substituted ketoesters, and involved the use of a large amount (50 mol \%) of the solid acid.

Considering the discussed above, and as part of our interest in environmentally desirable pathways to prepare natural and bioactive compounds, herein we describe the solvent-free synthesis of C4-substituted coumarins through the Pechmann condensation of activated and non-activated phenols with functionalized $\beta$-ketoesters. In this strategy, we investigate the possibility of using a low load of sulfamic acid while extending the reaction to differently functionalized $\beta$-ketoesters. Additionally, a detailed HRMS-based study was performed to prove the reaction mechanism.

\section{Results and Discussion}

For the synthesis of the C-4 substituted coumarin derivatives, we employed the phenols phloroglucinol (1a), resorcinol (1) $)$, pyrogallol (1c), 1-naphthol (1d), 3-methoxyphenol (1e), $m$-cresol (1f), and phenol (1g) in reactions with the $\beta$-ketoesters ethyl acetoacetate (2a), ethyl 4-chloroacetoacetate (2b), ethyl 4,4,4-trifluoroacetoacetate (2c), ethyl benzoylacetate (2d), and ethyl 4-azidoacetoacetate (2e). These phenols and $\beta$-ketoesters were commercially available, except for ethyl 4-azidoacetoacetate (2e), which was prepared according to a previously described procedure. ${ }^{30}$

In order to evaluate and optimize the reaction conditions, we conducted an initial experiment using equimolar amounts of ethyl acetoacetate $(2 \mathrm{a})(1 \mathrm{mmol})$ with phloroglucinol (1a) $(1 \mathrm{mmol})$ in the presence of SA (10 mol \%) into a septum-sealed reaction vial. The experiment was carried out at $130{ }^{\circ} \mathrm{C}$, for 40 minutes (Table 1, entry 1). Under this condition, coumarin 3a was produced in $20 \%$ isolated yield after ethanol-water recrystallization. Increasing the amount of the $\beta$-ketoester $\mathbf{2 a}$ to $1.2,1.5$, and 2 equivalents afforded $3 a$ in $40 \%, 84 \%$, and $84 \%$ yield, respectively (Table 1 entries $2-4$ ).

We subsequently studied the catalyst amount effect on the yield of the reaction. The decrease of the catalyst amount to $5 \mathrm{~mol} \%$, relative to phloroglucinol, afforded $3 \mathbf{3}$ in only $38 \%$ yield (entry 5 ). No product was detected with $2 \mathrm{~mol} \%$ (entry 6 ) or in the absence of the catalyst. Also, increasing the catalyst loading to $20 \mathrm{~mol} \%$ did not improve the yield of the desired product (entry 7). An attempt to decrease the temperature reaction also led to negative performance, decreasing the $3 a$ yield (entries 8 and 9). Increasing the reaction time from 40 to 60 minutes allowed $3 a$ in $88 \%$ yield (entry 10). However, increasing the reaction time did not show improvement in the yield (entry 11). 
Table 1. Reaction condition screening for the coumarin synthesis ${ }^{\mathrm{a}}$<smiles>CCOC(=O)CC(C)=O</smiles>

\begin{tabular}{cccccc}
\hline entry & $\begin{array}{c}\text { molar ratio } \\
(\mathbf{1 a : 2 a})\end{array}$ & $\begin{array}{c}\mathrm{NH}_{2} \mathrm{SO}_{3} \mathrm{H} \\
(\mathrm{mol} \%)\end{array}$ & temperature $\left({ }^{\circ} \mathrm{C}\right)$ & $\begin{array}{c}\text { time } \\
(\mathrm{min})\end{array}$ & $\begin{array}{c}\text { Yield }^{b} \\
(\%)\end{array}$ \\
\hline 1 & $1: 1$ & 10 & 130 & 40 & 20 \\
2 & $1: 1.2$ & 10 & 130 & 40 & 40 \\
3 & $1: 1.5$ & 10 & 130 & 40 & 84 \\
4 & $1: 2$ & 10 & 130 & 40 & 84 \\
5 & $1: 1.5$ & 5 & 130 & 40 & 38 \\
6 & $1: 1.5$ & 2 & 130 & 40 & $-\mathrm{c}$ \\
7 & $1: 1.5$ & 20 & 130 & 40 & 80 \\
8 & $1: 1.5$ & 10 & 80 & 40 & 65 \\
9 & $1: 1.5$ & 10 & 100 & 40 & 74 \\
10 & $1: 1.5$ & 10 & 130 & 60 & 88 \\
11 & $1: 1.5$ & 10 & 130 & 120 & 80 \\
\hline
\end{tabular}

a Reaction conditions: A mixture of phloroglucinol $1 \mathrm{a}(1 \mathrm{mmol}), \beta$-ketoester $2 \mathrm{a}$, and the catalyst was stirred in a sealed vial. ${ }^{b}$ Isolated yield after purification by recrystallization using ethanol. ' The starting materials were recovered.

With the optimized condition in hands (Table 1, entry 10), the scope of the method was evaluated for activated and non-activated phenols and $\beta$-ketoesters, including ethyl 4-chloroacetoacetate, ethyl benzoylacetate, ethyl 4,4,4-trifluoroacetoacetate, and ethyl 4-azidoacetoacetate. As shown in Table 2, very good yields were achieved for the coumarins 3a-c derived from ethyl acetoacetate $\mathbf{2} \mathbf{a}$ and activated phenols. The coumarin $3 c$, derived from pyrogallol, required a longer reaction time, and it was obtained with $82 \%$ yield after $4 \mathrm{~h}$.

For the reactions employing ethyl 4-chloroacetoacetate $(\mathbf{2 b})$, it was noticed that the reaction temperature of $100{ }^{\circ} \mathrm{C}$ led to better yields than the initially optimized temperature of $130{ }^{\circ} \mathrm{C}$. For example, the reaction between ethyl 4-chloroacetoacetate (2b) and phloroglucinol (1a) at $130{ }^{\circ} \mathrm{C}$ yielded $3 \mathbf{3 e}$ in $75 \%$ yield. When the reaction temperature was at $100{ }^{\circ} \mathrm{C}$, the product $3 \mathrm{e}$ was obtained in $86 \%$ yield in only 20 minutes. 
Table 2. Substrate scope for activated and deactivated phenols and $\beta$-ketoesters ${ }^{\mathrm{a}}$

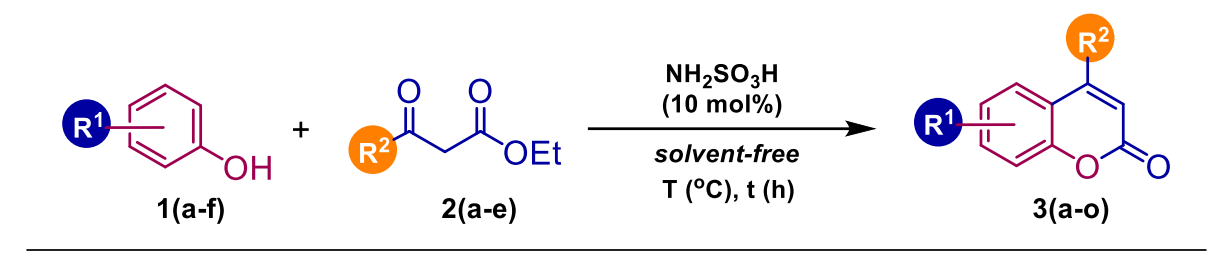

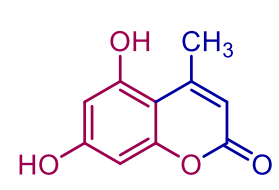

3a: $1 \mathrm{~h}, 88 \%$

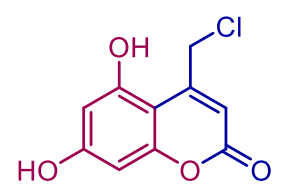

3e: $0.3 \mathrm{~h} \mathrm{(20} \mathrm{min),} 86 \%^{\mathrm{b}}$

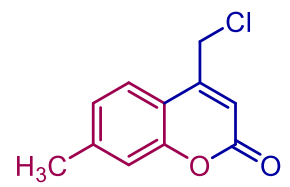

3i: 24 h, $52 \%^{b}$<smiles>Cc1cc(=O)oc2cc(O)ccc12</smiles>

3b: $1.5 \mathrm{~h}, 90 \%$<smiles>O=c1cc(CCl)c2ccc(O)c(O)c2o1</smiles>

3f: $1 \mathrm{~h}, 70 \%^{\mathrm{b}}$

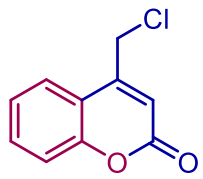

3j: 24 h, $26 \%^{b}$<smiles>Cc1cc(=O)oc2c(O)c(O)ccc12</smiles>

3c: $4 \mathrm{~h}, 82 \%$<smiles>O=c1cc(CCl)c2ccc3ccccc3c2o1</smiles>

3g: 6 h, $60 \%^{\mathrm{b}}$<smiles>O=c1cc(-c2ccccc2)c2ccc(O)cc2o1</smiles>

3k: 24 h, $60 \%$<smiles>O=c1cc(CCl)c2ccc(O)cc2o1</smiles>

3d: $1 \mathrm{~h}, 72 \%^{\mathrm{b}}$<smiles>O=c1cc(C(F)(F)F)c2ccc(O)cc2o1</smiles>

$3 \mathrm{~m}: 2 \mathrm{~h}, 60 \%$<smiles>O=c1cc(C(F)(F)F)c2ccc(O)c(O)c2o1</smiles>

3n: 3 h, $50 \%$<smiles>NCc1cc(=O)oc2cc(O)cc(O)c12</smiles>

3o: $1.5 \mathrm{~h}, 64 \%$<smiles>COc1ccc2c(CCl)cc(=O)oc2c1</smiles>

3h: $4 \mathrm{~h}, 90 \%^{\mathrm{b}}$<smiles>O=c1cc(-c2ccccc2)c2c(O)cc(O)cc2o1</smiles>

$3 \mathrm{I}: 18 \mathrm{~h}, 50 \%$

aReaction conditions: A mixture of phenol (10 mmol), $\beta$-ketoester (15 $\mathrm{mmol})$, and the catalyst $(0.097 \mathrm{~g}, 10 \mathrm{~mol} \%)$ was stirred in a sealed vial at $130{ }^{\circ} \mathrm{C}$ for the specified reaction time. ${ }^{b}$ Reactions carried out at $100^{\circ} \mathrm{C}$. All the given yields were registered after purification by recrystallization using ethanol.

When pyrogallol (1c) was employed as the phenol partner, the coumarin $\mathbf{3 f}$ was obtained in $70 \%$ yield after $1 \mathrm{~h}$ of reaction, while the condensation of 1-naphthol (1d) with $\mathbf{2} \mathbf{b}$ gave the corresponding coumarin $\mathbf{3 g}$ in $60 \%$ yield.

A very good yield of $90 \%$ for the coumarin $\mathbf{3 h}$, obtained from the condensation of 3-methoxyphenol (1e) and $\mathbf{2 b}$ was achieved, but after a longer reaction time of $4 \mathrm{~h}$. It was noticed that sulfamic acid did not improve the yield for the condensation of the non-activated $m$-cresol (1) and phenol (19), which afforded the corresponding coumarins $3 \mathbf{i}$ and $\mathbf{3} \mathbf{j}$ in only $52 \%$ and $26 \%$ yield, respectively, after $24 \mathrm{~h}$. Ethyl benzoylacetate (2d) was also evaluated as $\beta$-ketoester partner in reactions with resorcinol (1) $)$ and phloroglucinol (1a) and, as expected due to the low electrophilicity of the carbonyl group, the respective coumarins $\mathbf{3 k}$ and $\mathbf{3} \mathbf{l}$ were obtained in moderate yields (up to 60\%) using longer reaction times (18-24 h). When the reactions were 
performed using 4,4,4-trifluoroacetoacetate (2d) as the $\beta$-ketoester partner, the 4-(trifluoromethyl)coumarins $3 \mathrm{~m}$ and $3 \mathrm{n}$ were obtained in moderate yields of $60 \%$ and $50 \%$, respectively. The azido-containing coumarin 30 was prepared in a good yield of $64 \%$, after $1.5 \mathrm{~h}$ by the condensation of ethyl 4 -azidoacetoacetate (2e) and phloroglucinol (1a). This is an especially valuable compound once the presence of the azido group allows its transformation into amine, amide, triazole, or tetrazole derivatives, which could be applied as building blocks in the synthesis of drug candidates ${ }^{31}$ or fluorescent sensors. ${ }^{32}$ This compound is generally obtained by the nucleophilic substitution of the C4-substituted 4-(chloromethyl)coumarins.

Sulfamic acid was described as a heterogeneous catalyst with a possibility for recovery and reuse. However, the attempt to recover the catalyst showed a catalyst mass loss of $20 \%$, which is resulted from the slight solubility of sulfamic acid in ethanol employed in the extraction step. The mass of the recovered catalyst was applied in a subsequent reaction for the synthesis of coumarin 3a, and the amount of phloroglucinol (1a) and ethyl acetoacetate (2a) was adjusted to maintain the catalyst and phenol 1a molar ratio at $10 \mathrm{~mol} \%$. The coumarin $3 a$ was obtained with $76 \%$ yield, which represents a decrease of $13.6 \%$.

Finally, to demonstrate the robustness and usefulness of the proposed method, we scaled up the synthesis of coumarin derivatives $\mathbf{3 a}$ and $\mathbf{3 e}$ from the condensation of phloroglucinol (1a) and ethyl acetoacetate (2a) or ethyl chloroacetate (2b), respectively. The reactions were carried out in an open vessel equipped with a condenser, following the optimized conditions shown in Table 1, entry 10. For both examples, a slight decrease in the coumarin yield was noticed, compared to the reaction in $10 \mathrm{mmol}$ scale. The coumarin 3a was obtained in $76 \%$ yield $(11.4 \mathrm{~g})$, while the coumarin $3 \mathrm{e}$ was obtained in $78 \%$ yield (3.5 g) after purification (Scheme 1).

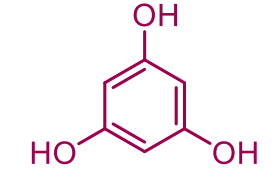

$1 \mathbf{a}$

$(9.84 \mathrm{~g}, 0.078 \mathrm{~mol})$

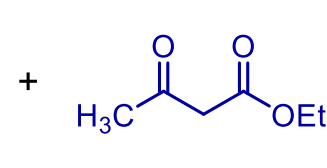

2a

(15.23 g, $0.117 \mathrm{~mol})$

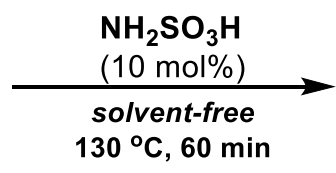

$30^{\circ} \mathrm{C}, 60 \mathrm{~min}$

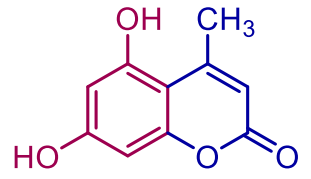

$3 a$

$11.4 \mathrm{~g}(76 \%)$

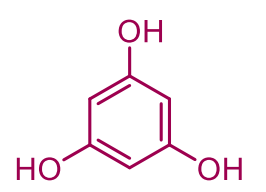

$1 \mathrm{a}$

(2.52 g, $0.02 \mathrm{~mol})$

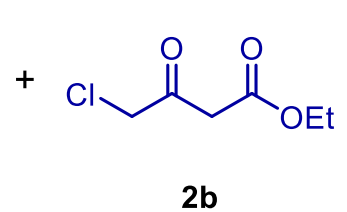

$(4.94 \mathrm{~g}, 0.03 \mathrm{~mol})$

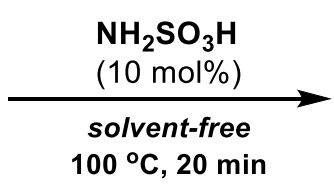

solvent-free
$100^{\circ} \mathrm{C}, 20 \mathrm{~min}$

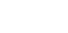

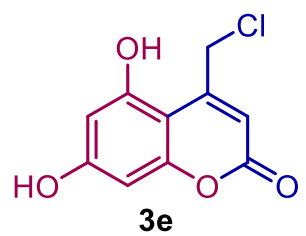

$3.5 \mathrm{~g}(78 \%)$

Scheme 1. Gram-scale synthesis of the coumarin derivatives $\mathbf{3 a}$ and $\mathbf{3 e .}$

Despite the importance of the Pechmann condensation, there are few studies that address the role of the catalyst, or of the nature of the phenols, or even of the $\beta$-ketoester in the reaction mechanism. ${ }^{16}$ Two $^{2}$ plausible mechanisms have been proposed for the Pechmann condensation. The first was proposed by Robertson in 1932, ${ }^{33}$ which is initiated by an electrophilic aromatic substitution followed by an intramolecular transesterification and a dehydration reaction. However, the order of the last two steps has not yet been identified. The second plausible mechanism was proposed by Ahmed and Desai ${ }^{34}$ and involves a transesterification reaction as the first step, followed by an electrophilic aromatic substitution and dehydration reaction, or vice-versa. 
Therefore, to gain some understanding on the role of sulfamic acid in the reaction mechanism, we performed a study employing high-resolution mass spectrometry (HRMS). Ethyl 4-chloroacetoacetate $\mathbf{2} \mathbf{b}$ was chosen due to the presence of the chlorine atom, which leads to a unique isotopic pattern, thus helping in the characterization of the intermediate(s). $m$-Cresol (1f) was chosen as the phenol partner due to the long reaction time to obtain the coumarin $\mathbf{3 h}$, allowing the identification of possible intermediates.

As the reaction took place, aliquots were collected, quickly solubilized in ethanol, filtered, and immediately direct-injected in the electrospray ionization (ESI) source. Along with the experiment, it was possible to detect the protonated molecule $[\mathrm{M}+\mathrm{H}]^{+}$with $\mathrm{m} / \mathrm{z}$ 271.0740. The accurate mass and isotopic pattern suggest the molecular formula $\mathrm{C}_{13} \mathrm{H}_{15} \mathrm{ClO}_{4}$, which indicates the proposed intermediate II.

To confirm the chemical identity of the intermediate II, it was performed a tandem mass spectrometry (ESI-MS/MS) experiment, in which the product-ions are consistent with II, excluding the possibility of assign the ion with $\mathrm{m} / \mathrm{z} 271.0740$ to the intermediate III (same $\mathrm{m} / \mathrm{z}$ for $[\mathrm{M}+\mathrm{H}]^{+}$). The detailed experimental procedure and HRMS spectra are provided in the supplementary material.
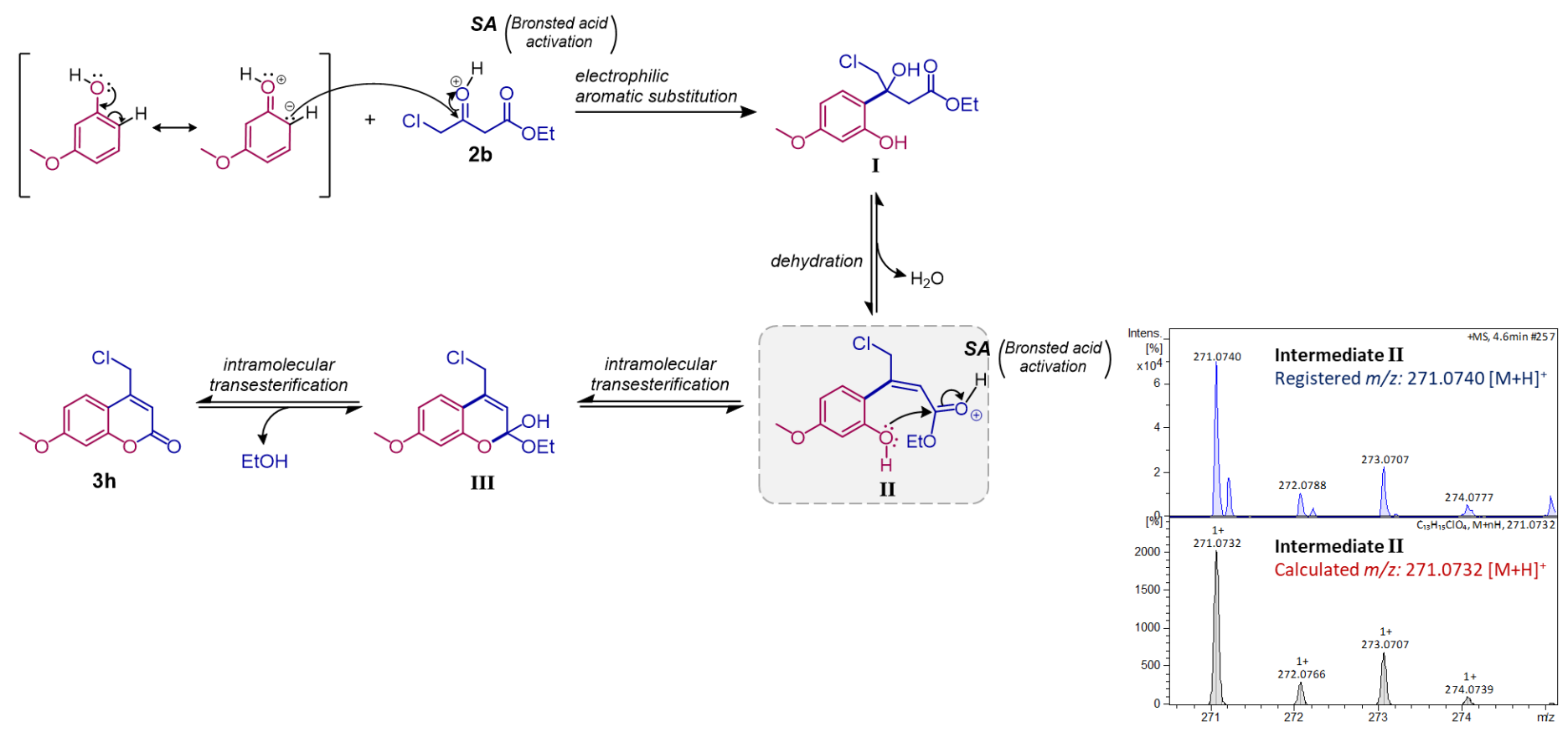

Scheme 2. A plausive mechanism for the sulfamic acid-catalyzed Pechmann condensation of $\mathbf{1 f}$ and $\mathbf{2 b}$. Involvement of the intermediate II identified by HRMS analysis.

Unfortunately, the other expected intermediates could not be observed. To exclude the possibility that the intermediate II was formed in the ionization source, a reaction mixture of $\mathbf{1} \mathbf{f}$ and $\mathbf{2} \mathbf{b}$ was stirred for 30 minutes at $25^{\circ} \mathrm{C}$. An aliquot was solubilized in ethanol, filtered, and direct-injected in the ESI source. Only the mass peaks assigned to $\mathbf{1} \mathbf{f}$ and $\mathbf{2} \mathbf{b}$ were observed in the negative and positive ion mode, respectively.

According to the theoretical studies by Daru and Stirling, ${ }^{35}$ who evaluated three possible reaction pathways by DFT calculations using ethyl acetoacetate as $\beta$-ketoester and resorcinol as model substrates, the cinnamic ester derivative is very prone to be isolated due to the higher activation energy of this intermediate. In contrast, the Gibbs free energy profile for the other intermediates suggests a very short lifetime. The cinnamic ester derivative was also reported as a side product of the Pechmann condensation. ${ }^{20}$ 
Tyndall and coauthors $^{36}$ monitored the reaction between resorcinol (1b) and ethyl 4,4,4trifluoroacetoacetate $(2 \mathrm{c})$ using ${ }^{19} \mathrm{~F} \mathrm{NMR}$ and $1^{\mathrm{H}} \mathrm{NMR}$. In this study, iodine was used as catalyst and toluene as solvent. From the two intermediates observed in the pathway to 7-hydroxy-4- (trifluoromethyl)coumarin (3m), the first indicates the electrophilic aromatic substitution as the first step of the reaction mechanism. The second intermediate, however, indicates that the transesterification step occurs prior to the dehydration step.

Thus, the observation of intermediate II indicates that SA catalyzes the Pechmann condensation by activating the $\beta$-ketoester and promoting an electrophilic aromatic substitution as the first step, followed by dehydration and finally the intermolecular transesterification reaction to give the expected product $\mathbf{3}$, as suggested in Scheme 2.

Although the herein-discussed studies corroborated with the observed intermediate II and the proposed electrophilic aromatic substitution as the first step under the evaluated reaction conditions, the Pechmann condensation mechanism is still controversial. For instance, EL-Dafrawy and coauthors ${ }^{37}$ investigated the kinetic parameters of the Pechmann condensation between resorcinol (1) and ethyl acetoacetate (2a) under reflux conditions and in the presence of the zinc oxide supported on sulfated zirconia as catalyst. The experimental results showed that the transesterification step is the rate-determining step. However, no intermediate was isolated or spectroscopically characterized.

\section{Conclusions}

We presented in this study the catalytic activity of sulfamic acid (SA) for the synthesis of C4-functionalized coumarins with activated and non-activated phenols and $\beta$-ketoesters. The coumarins were prepared in moderate to excellent yields, and the optimized and feasible methodology allows the synthesis on a gram scale under solvent-free conditions. Also, the preliminary insight into the possible intermediates using HRMS experiments contributes to an increased understanding of the mechanism of Pechmann's condensation. The detection of the cinnamic ester derivative suggests that SA promotes an electrophilic aromatic substitution as the first step, followed by dehydration and the intermolecular transesterification reaction as the last step.

\section{Experimental Section}

General. Unless otherwise indicated, all common reagents and solvents were used as obtained from commercial suppliers without further purification. The NMR experiments were performed on a Bruker Fourier 300 FT-NMR spectrometer (7.05 T, $300 \mathrm{MHz}$ for ${ }^{1} \mathrm{H}, 75.48 \mathrm{MHz}$ for $\left.{ }^{13} \mathrm{C}\right)$. The chemical shifts $(\delta)$ are expressed in part per million (ppm), and the coupling constants are reported in $\mathrm{Hz}$. The spectra were acquired at a temperature of $293 \mathrm{~K}$, using $5 \mathrm{~mm}$ quartz tubes. For the NMR data acquisition and processing, the TopSpin ${ }^{\mathrm{TM}}$ software (Bruker) was used. The high-resolution electrospray ionization mass spectrometry (ESI-QTOF) analyses were performed on a Bruker Daltonics micrOTOF-Q II instrument in positive mode, under the following conditions: capillary and cone voltages were set to $+3500 \mathrm{~V}$ and $+40 \mathrm{~V}$, respectively, with a desolvation temperature of $200{ }^{\circ} \mathrm{C}$. The samples were solubilized in HPLC-grade methanol, containing $0.1 \%$ formic acid, and injected into the ESI source by means of a syringe pump at a flow rate of $5.0 \mu \mathrm{L} \mathrm{min}{ }^{-1}$. Melting points were recorded on a Fisatom capillary melting point apparatus, model 431, with a measurement range from $50^{\circ} \mathrm{C}$ to $350^{\circ} \mathrm{C}$ and are uncorrected. 
Synthetic procedures and characterization data for products 3a-o. A mixture of the phenol (1a-g) (1 mmol) with the $\beta$-ketoester (2a-e) $(1.5 \mathrm{mmol})$ was added to a sealed reaction vial in the presence of sulfamic acid $(0.097 \mathrm{~g}, 10 \mathrm{~mol} \%)$, and then the reaction mixture was heated to $130{ }^{\circ} \mathrm{C}$ or $100{ }^{\circ} \mathrm{C}$ (depending on the $\beta$ ketoester employed) and the appropriated reaction time (see Table 2). After completion, the reaction mixture was cooled to room temperature and dissolved in $5 \mathrm{~mL}$ of hot ethanol. Sulfamic acid is partially soluble in ethanol and is filtered off and recovered. Afterward, ice water and crushed ice were added until the product precipitated. The compound was then filtered, washed with water, and dried under lyophilization given the final product. The products $\mathbf{3 d}, \mathbf{3 f}, \mathbf{3} \mathbf{3}, \mathbf{3 n}$ were further purified by flash column chromatography to yield the pure products (hexane/ethyl acetate 7:3).

5,7-Dihydroxy-4-methyl-2H-chromen-2-one (3a). White solid; mp $286-288{ }^{\circ} \mathrm{C}\left(288-290{ }^{\circ} \mathrm{C}^{38}\right) .{ }^{1} \mathrm{H} \mathrm{NMR}(300$ $\mathrm{MHz}$, acetone-d $)_{6} \delta 2.55(\mathrm{~d}, J 1.2 \mathrm{~Hz}, 3 \mathrm{H}), 5.84(\mathrm{q}, J 1.2 \mathrm{~Hz}, 1 \mathrm{H}), 6.27(\mathrm{~d}, J 2.4 \mathrm{~Hz}, 1 \mathrm{H}), 6.35(\mathrm{~d}, J 2.4 \mathrm{~Hz}, 1 \mathrm{H}), 9.29$ $(\mathrm{s}, 1 \mathrm{H}, \mathrm{OH}), 9.55$ (s, $1 \mathrm{H}, \mathrm{OH}) .{ }^{13} \mathrm{C}$ NMR $\left(75 \mathrm{MHz}, \mathrm{DMSO}-d_{6}\right) \delta$ 23.49, 94.64, 99.11, 102.18, 108.94, 155.10, 156.57, 158.02, 160.22, 161.13. HRMS (ESI+) calcd. mass for $\mathrm{C}_{10} \mathrm{H}_{9} \mathrm{O}_{4}[\mathrm{M}+\mathrm{H}]^{+}$193.0495, found: 193.0496.

7-Hydroxy-4-methyl-2H-chromen-2-one (3b). Light yellow solid; mp $180-182{ }^{\circ} \mathrm{C}\left(183-185{ }^{\circ} \mathrm{C}^{38}\right) .{ }^{1} \mathrm{H} \mathrm{NMR}(300$ $\mathrm{MHz}$, acetone- $\left.d_{6}\right) \delta 2.41(\mathrm{~d}, J 1.2 \mathrm{~Hz}, 3 \mathrm{H}), 6.08(\mathrm{q}, J 1.2 \mathrm{~Hz}, 1 \mathrm{H}), 6.74(\mathrm{~d}, J 2.4 \mathrm{~Hz}, 1 \mathrm{H}), 6.86(\mathrm{dd}, J 8.7$ and $J 2.4$ $\mathrm{Hz}, 1 \mathrm{H}), 7.61(\mathrm{~d}, J 8.7 \mathrm{~Hz}, 1 \mathrm{H}), 9.47(\mathrm{~s}, 1 \mathrm{H}, \mathrm{OH}) .{ }^{13} \mathrm{C}$ NMR $\left(75 \mathrm{MHz}, \mathrm{DMSO}-d_{6}\right) \delta 18.14,102.21,110.31,112.02$, $112.86,126.52,153.46,154.86,160.34,161.19$. HRMS (ESI+) calcd. mass for $\mathrm{C}_{10} \mathrm{H}_{9} \mathrm{O}_{3}[\mathrm{M}+\mathrm{H}]^{+} 177.0546$, found: 177.0548.

7,8-Dihydroxy-4-methyl-2H-chromen-2-one (3c). White solid; mp 235-237 ${ }^{\circ} \mathrm{C}\left(240-242{ }^{\circ} \mathrm{C}^{38}\right) .{ }^{1} \mathrm{H} \mathrm{NMR}(300$ MHz, DMSO-d $) \delta 2.34(\mathrm{~d}, J 1.2 \mathrm{~Hz}, 3 \mathrm{H}), 6.12(\mathrm{q}, J 1.2 \mathrm{~Hz}, 1 \mathrm{H}), 6.80(\mathrm{~d}, J 8.7 \mathrm{~Hz}, 1 \mathrm{H}), 7.08(\mathrm{~d}, J 8.7 \mathrm{~Hz}, 1 \mathrm{H}), 9.32$ (s, $1 \mathrm{H}, \mathrm{OH}), 10.08$ (s, $1 \mathrm{H}, \mathrm{OH}) .{ }^{13} \mathrm{C}$ NMR (75 MHz, DMSO-d $) \delta 18.31,110.26,112.18,112.83,115.52,132.22$, 143.37, 149.45, 153.98, 160.30. HRMS (ESI+) calcd. Mass for $\mathrm{C}_{10} \mathrm{H}_{9} \mathrm{O}_{4}[\mathrm{M}+\mathrm{H}]^{+}$193.0495, found: 193.0495.

4-(Chloromethyl)-7-hydroxy-2H-chromen-2-one (3d). Light yellow solid; mp $182-184{ }^{\circ} \mathrm{C}\left(184-185{ }^{\circ} \mathrm{C}^{39}\right) .{ }^{1} \mathrm{H}$ NMR (300 MHz, DMSO-d $) \delta 4.95$ (d, J 1.2 Hz, 2H), $6.41(\mathrm{~s}, 1 \mathrm{H}), 6.75$ (d, J $2.4 \mathrm{~Hz}), 6.84$ (dd, J 8.7 and J 2.4 Hz), 7.67 (d, J 8.7 Hz), 10.67 (s, 1H, OH). ${ }^{13} \mathrm{C}$ NMR (75 MHz, DMSO-d 6 ) $\delta$ 41.42, 102.57, 109.39, 111.09, 113.14, 126.57, 151.00, 155.34, 160.23, 161.51. HRMS (ESI+) calcd. mass for $\mathrm{C}_{10} \mathrm{H}_{8} \mathrm{ClO}_{3}[\mathrm{M}+\mathrm{H}]^{+} 211.0156$, found: 211.0154.

4-(Chloromethyl)-5,7-dihydroxy-2H-chromen-2-one (3e). White solid; mp 231-233 ${ }^{\circ} \mathrm{C}\left(240-242{ }^{\circ} \mathrm{C}^{40}\right) .{ }^{1} \mathrm{H} \mathrm{NMR}$ (300 MHz, acetone- $\left.d_{6}\right) \delta 5.07(\mathrm{~d}, J 1.2 \mathrm{~Hz}, 2 \mathrm{H}), 6.28(\mathrm{t}, J 1.2 \mathrm{~Hz}, 1 \mathrm{H}), 6.32(\mathrm{~d}, J 2.4 \mathrm{~Hz}, 1 \mathrm{H}), 6.38(\mathrm{~d}, J 2.4 \mathrm{~Hz}, 1 \mathrm{H})$, $9.35(\mathrm{~s}, 1 \mathrm{H}, \mathrm{OH}), 9.85$ (s, 1H, OH). ${ }^{13} \mathrm{C} \mathrm{NMR}\left(75 \mathrm{MHz}, \mathrm{DMSO}-d_{6}\right) \delta$ 45.11, 94.89, 99.32, 99.88, 108.84, 152.15, 156.59, 157.25, 160.19, 161.63. HRMS (ESI+) calcd. mass for $\mathrm{C}_{10} \mathrm{H}_{8} \mathrm{ClO}_{4}[\mathrm{M}+\mathrm{H}]^{+}$227.0105, found: 227.0101.

4-(Chloromethyl)-7,8-dihydroxy-2H-chromen-2-one (3f). Light yellow solid; mp $194-196{ }^{\circ} \mathrm{C}\left(196-198{ }^{\circ} \mathrm{C}^{39}\right) .{ }^{1} \mathrm{H}$ NMR (300 MHz, DMSO-d $) \delta 4.93(\mathrm{~s}, 2 \mathrm{H}), 6.41(\mathrm{~s}, 1 \mathrm{H}), 6.84(\mathrm{~d}, J 8.7 \mathrm{~Hz}, 1 \mathrm{H}), 7.17(\mathrm{~d}, J 8.7 \mathrm{~Hz}, 1 \mathrm{H}), 9.41(\mathrm{~s}, 1 \mathrm{H}$, $\mathrm{OH}), 10.21(\mathrm{~s}, 1 \mathrm{H}, \mathrm{OH}) .{ }^{13} \mathrm{C}$ NMR $\left(75 \mathrm{MHz}, \mathrm{DMSO}-d_{6}\right) \delta 41.56,110.17,111.01,112.38,115.54,132.52,143.73$, 149.82, 151.46, 160.18. HRMS (ESI+) calcd. Mass for $\mathrm{C}_{10} \mathrm{H}_{8} \mathrm{ClO}_{4}[\mathrm{M}+\mathrm{H}]^{+} 227.0105$, found: 227.0105 .

4-(Chloromethyl)-2H-benzo[h]chromen-2-one (3g). Light brown solid; mp 154-156 ${ }^{\circ} \mathrm{C}\left(159-161{ }^{\circ} \mathrm{C}^{40}\right) .{ }^{1} \mathrm{H} \mathrm{NMR}$ $\left(300 \mathrm{MHz}, \mathrm{DMSO}-d_{6}\right) \delta 5.12\left(\mathrm{~s}, 2 \mathrm{H}, \mathrm{CH}_{2}\right), 6.80(\mathrm{~s}, 1 \mathrm{H}, \mathrm{CH}), 7.76-7.69(\mathrm{~m}, 2 \mathrm{H}), 7.91-7.83(\mathrm{~m}, 2 \mathrm{H}), 8.06-8.03(\mathrm{~m}$, $1 \mathrm{H}), 8.37-8.34(\mathrm{~m}, 1 \mathrm{H}) .{ }^{13} \mathrm{C}$ NMR $\left(75 \mathrm{MHz}, \mathrm{DMSO}-d_{6}\right) \delta 41.67,112.80,114.87,120.92,121.62,122.24,124.09$, $127.55,128.00,128.99,134.37,150.34,151.447$ 159.53. HRMS (ESI+) calcd. mass for $\mathrm{C}_{14} \mathrm{H}_{10} \mathrm{ClO}{ }_{2}[\mathrm{M}+\mathrm{H}]^{+}$ 245.0364, found: 245.0369.

4-(Chloromethyl)-7-methoxy-2H-chromen-2-one (3h). White solid; mp 195-197 ${ }^{\circ} \mathrm{C}\left(198-201{ }^{\circ} \mathrm{C}^{41}\right) .{ }^{1} \mathrm{H} \mathrm{NMR}$ $\left(300 \mathrm{MHz}, \mathrm{DMSO}-d_{6}\right) \delta 3.86\left(\mathrm{~s}, 3 \mathrm{H}, \mathrm{OCH}_{3}\right), 4.98\left(\mathrm{~s}, 2 \mathrm{H}, \mathrm{CH}_{2}\right), 6.49(\mathrm{~s}, 1 \mathrm{H}), 7.01(\mathrm{dd}, J 2.4 \mathrm{~Hz}$ and $J 8.7 \mathrm{~Hz}, 1 \mathrm{H})$, $7.04(\mathrm{~d}, J 2.4 \mathrm{~Hz}, 1 \mathrm{H}), 7.77$ (d, J $8.7 \mathrm{~Hz}, 1 \mathrm{H}) .{ }^{13} \mathrm{C}$ NMR (75 MHz, DMSO-d $)$ ) 41.37, 55.98, 101.06, 110.46, 
112.02, 112.36, 126.38, 150.86, 155.28, 160.04, 162.62. HRMS (ESI+) calcd. mass for $\mathrm{C}_{11} \mathrm{H}_{10} \mathrm{ClO} \mathrm{O}_{3}[\mathrm{M}+\mathrm{H}]^{+}$ 225.0313, found: 225.0309.

4-(Chloromethyl)-7-methyl-2H-chromen-2-one (3i). White solid; mp $215-217{ }^{\circ} \mathrm{C}\left(215-216{ }^{\circ} \mathrm{C}^{39}\right) .{ }^{1} \mathrm{H}$ NMR $(300$ $\left.\mathrm{MHz}_{2} \mathrm{CDCl}_{3}\right) \delta 2.46(\mathrm{~s}, 3 \mathrm{H}), 4.65(\mathrm{~d}, J 1.2 \mathrm{~Hz}, 2 \mathrm{H}), 6.51(\mathrm{~s}, 1 \mathrm{H}), 7.13-7.18(\mathrm{~m}, 2 \mathrm{H}), 7.54(\mathrm{~d}, J 8.4 \mathrm{~Hz}, 1 \mathrm{H}) .{ }^{13} \mathrm{C} \mathrm{NMR}$ $\left(75 \mathrm{MHz}, \mathrm{CDCl}_{3}\right) \delta 21.85,41.64,114.93,117.73,117.99,123.92,125.84,143.79,149.64,154.08,160.75 . \mathrm{HRMS}$ $(\mathrm{ESI}+)$ calcd. Mass for $\mathrm{C}_{11} \mathrm{H}_{10} \mathrm{ClO}_{2}[\mathrm{M}+\mathrm{H}]^{+} 209.0364$, found: 209.0364 .

4-(Chloromethyl)-2H-chromen-2-one (3j). White solid; mp $144-145{ }^{\circ} \mathrm{C}\left(144-145{ }^{\circ} \mathrm{C}^{39}\right) .{ }^{1} \mathrm{H} \mathrm{NMR}(300 \mathrm{MHz}$, $\left.\mathrm{CDCl}_{3}\right) \delta 4.68(\mathrm{~s}, 2 \mathrm{H}), 6.58(\mathrm{~s}, 1 \mathrm{H}), 7.31-7.40(\mathrm{~m}, 2 \mathrm{H}), 7.58(\mathrm{td}, J 1.4 \mathrm{~Hz}$ and J $7.24 \mathrm{~Hz}, 1 \mathrm{H}), 7.68$ (dd, J $1.4 \mathrm{~Hz}$ and J $8.1 \mathrm{~Hz}, 1 \mathrm{H}) .{ }^{13} \mathrm{C}$ NMR $\left(75 \mathrm{MHz}, \mathrm{CDCl}_{3}\right) \delta .41 .45,116.14,117.47,117.70,124.34,124.73,132.51,149.65$, 154.02, 160.45. HRMS (ESI+) calcd. mass for $\mathrm{C}_{10} \mathrm{H}_{8} \mathrm{ClO}_{2}[\mathrm{M}+\mathrm{H}]^{+} 195.0207$, found: 195.0200 .

7-Hydroxy-4-phenyl-2H-chromen-2-one (3k). White solid; mp $233-235{ }^{\circ} \mathrm{C}\left(242-244{ }^{\circ} \mathrm{C}^{42}\right) .{ }^{1} \mathrm{H} \mathrm{NMR}(300 \mathrm{MHz}$, DMSO-d $)_{6} \delta 6.15(\mathrm{~s}, 1 \mathrm{H}), 6.76-6.81(\mathrm{~m}, 2 \mathrm{H}), 7.27(\mathrm{~d}, J 8.7 \mathrm{~Hz}, 1 \mathrm{H}), 7.50-7.57(\mathrm{~m}, 5 \mathrm{H}), 10.67(\mathrm{~s}, 1 \mathrm{H}, \mathrm{OH}) .{ }^{13} \mathrm{C}$ NMR $\left(75 \mathrm{MHz}, \mathrm{DMSO}-d_{6}\right) \delta 102.74,110.41,110.7,113.24,128.16,128.45,128.86,129.62,135.22,155.45$, 155.60, 160.18, 161.45. HRMS (ESI+) calcd. mass for $\mathrm{C}_{15} \mathrm{H}_{11} \mathrm{O}_{3}[\mathrm{M}+\mathrm{H}]^{+} 239.0702$, found: 239.0704 .

5,7-Dihydroxy-4-phenyl-2H-chromen-2-one (3l). White solid; mp 232-234 ${ }^{\circ} \mathrm{C}\left(242-244{ }^{\circ} \mathrm{C}^{42}\right) .{ }^{1} \mathrm{H} \mathrm{NMR}(300$ MHz, DMSO-d $) \delta 5.74(\mathrm{~s}, 1 \mathrm{H}), 6.15$ (d, J $2.4 \mathrm{~Hz}, 1 \mathrm{H}), 6.26$ (d, J $2.4 \mathrm{~Hz}, 1 \mathrm{H}), 7.31-7.37(\mathrm{~m}, 5 \mathrm{H}), 10.13(\mathrm{~s}, 1 \mathrm{H}$, $\mathrm{OH}), 10.42(\mathrm{~s}, 1 \mathrm{H}, \mathrm{OH}) .{ }^{13} \mathrm{C}$ NMR $\left(75 \mathrm{MHz}, \mathrm{DMSO}-d_{6}\right) \delta 94.72,99.18,100.64,110.25,127.31,127.46,127.83$, $139.64,156.07,156.83,157.16,159.98,161.78$. HRMS (ESI+) calcd. mass for $\mathrm{C}_{15} \mathrm{H}_{11} \mathrm{O}_{4}[\mathrm{M}+\mathrm{H}]^{+} 255.0651$, found: 255.0645.

7-Hydroxy-4-(trifluoromethyl)-2H-chromen-2-one (3m). White solid; mp $186-188{ }^{\circ} \mathrm{C}\left(183-184{ }^{\circ} \mathrm{C}^{42}\right) .{ }^{1} \mathrm{H}$ NMR (300 MHz, DMSO-d $\left.d_{6}\right) \delta 6.75(\mathrm{~s}, 1 \mathrm{H}), 6.84(\mathrm{~d}, J 2.4 \mathrm{~Hz}, 1 \mathrm{H}), 6.90(\mathrm{dd}, J 8.7$ and J $2.4 \mathrm{~Hz}, 1 \mathrm{H}), 7.53-7.57(\mathrm{~m}, 1 \mathrm{H})$, $10.98(\mathrm{~s}, 1 \mathrm{H}, \mathrm{OH}) .{ }^{13} \mathrm{C}$ NMR $\left(75 \mathrm{MHz}, \mathrm{DMSO}-d_{6}\right) \delta 103.19,105.26,112.02\left(\mathrm{q},{ }^{3} \mathrm{~J}_{\mathrm{C}-\mathrm{F}} 5.77 \mathrm{~Hz}\right), 114.11,121.82(\mathrm{q}$, $\left.{ }^{1} J_{C-F} 275.5 \mathrm{~Hz}\right), 126.19,139.76\left(q,{ }^{2} J_{C-F} 31.96 \mathrm{~Hz}\right), 155.96,158.94,162.23$. HRMS (ESI+) calcd. mass for $\mathrm{C}_{10} \mathrm{H}_{6} \mathrm{~F}_{3} \mathrm{O}_{3}$ $[\mathrm{M}+\mathrm{H}]^{+} 231.0263$, found: 231.0268 .

7,8-Dihydroxy-4-(trifluoromethyl)-2H-chromen-2-one (3n). White solid; mp 203-205 ${ }^{\circ} \mathrm{C}\left(202-203{ }^{\circ} \mathrm{C}^{42}\right)$. ${ }^{1} \mathrm{H}$ NMR $\left(300 \mathrm{MHz}, \mathrm{DMSO}-d_{6}\right) \delta 6.73(\mathrm{~s}, 1 \mathrm{H}), 6.90(\mathrm{~d}, J 9 \mathrm{~Hz}, 1 \mathrm{H}), 7.02-7.09(\mathrm{~m}, 1 \mathrm{H}) .{ }^{13} \mathrm{C} \mathrm{NMR}(75 \mathrm{MHz}$, DMSO- $\left.d_{6}\right) \delta 106.04,111.81\left(q,{ }^{3} J_{C-F} 5.7 \mathrm{~Hz}\right), 113.20,115.29,121.98\left(q,{ }^{1} J_{C-F} 275.6 \mathrm{~Hz}\right), 133.01,140.27\left(q,{ }^{2} J_{C-F}\right.$ 31.85 Hz), 144.13, 150.64, 158.92. HRMS (ESI+) calcd. Mass for $\mathrm{C}_{10} \mathrm{H}_{6} \mathrm{~F}_{3} \mathrm{O}_{4}[\mathrm{M}+\mathrm{H}]^{+}$247.0212, found: 247.0212.

4-(Azidomethyl)-5,7-dihydroxy-2H-chromen-2-one (3o). White solid; mp 215-217 ${ }^{\circ} \mathrm{C}\left(220-221{ }^{\circ} \mathrm{C}^{39}\right) .{ }^{1} \mathrm{H} N M R$ $\left(300 \mathrm{MHz}, \mathrm{DMSO}-d_{6}\right) \delta 4.88$ (d, J $\left.1.2 \mathrm{~Hz}, 2 \mathrm{H}\right), 6.05(\mathrm{t}, J 1.2 \mathrm{~Hz}, 1 \mathrm{H}), 6.20(\mathrm{~d}, J 2.4 \mathrm{~Hz}, 1 \mathrm{H}), 6.28(\mathrm{~d}, J 2.4 \mathrm{~Hz}, 1 \mathrm{H})$. ${ }^{13} \mathrm{C}$ NMR $\left(75 \mathrm{MHz}\right.$, DMSO- $\left.d_{6}\right) \delta 52.90,94.83,99.11,100.07,106.72,151.77,156.53,157.31,160.09,161.56$. HRMS (ESI+) calcd. mass for $\mathrm{C}_{10} \mathrm{H}_{7} \mathrm{~N}_{3} \mathrm{O}_{4} \mathrm{Na}[\mathrm{M}+\mathrm{Na}]^{+} 256.0328$, found: 256.0325 .

\section{Catalyst recovery and reuse}

The sulfamic acid recovered by filtration after the reaction between the phenol (1a) and the $\beta$-ketoester (2a), under the conditions described in the synthetic procedure, was dried at $80{ }^{\circ} \mathrm{C}$ for $2 \mathrm{~h}$. The resulting mass of $0,078 \mathrm{~g}$ was used without the addition of sulfamic acid, and the amounts of $1 \mathrm{a}$ and $2 \mathrm{a}$ were adjusted $(0,8$ mmol and 1,2 mmol, respectively) to keep the catalyst and phenol $1 \mathrm{a}$ molar ratio at $10 \mathrm{~mol} \%$. The reaction was carried out as mentioned in the synthetic procedure. The coumarin 3a was obtained with $76 \%$ yield.

Mechanistic investigation by identification of intermediates by HRMS (ESI+) and Tandem mass spectrometry (ESI-MS/MS). For mechanistic investigation, aliquots were taken directly from the reaction mixture, immediately solubilized in $\mathrm{MeOH}$, and inject into the ESI source at a constant flow rate of $3 \mu \mathrm{L} \mathrm{min}{ }^{-1}$. The experiments were performed using a Bruker Daltonics micrOTOF-Q II instrument equipped with an ESI source operating in positive mode. The Acquisition parameters were: capillary: $4000 \mathrm{~V}$, endplate offset: $-500 \mathrm{~V}$, 
nebulizer: 0.4 bar, dry gas: $4.0 \mathrm{~L} \mathrm{~min}^{-1}$, and dry heater: $180{ }^{\circ} \mathrm{C}$. The collision cell energy was set to $20.0 \mathrm{eV}$. The spectra analyses and simulate pattern was performed with Bruker Compass Data Analysis 4.3 software.

\section{Acknowledgments}

The authors are grateful to Conselho Nacional de Desenvolvimento Científico e Tecnológico - CNPq (N431084/2018-1), FAPERGS, and FINEP for financial support. Coordenação de Aperfeiçoamento de Pessoal de Nível Superior - Brasil (CAPES) - Finance Code 001, is also acknowledged for the doctoral fellowship of M.C.M., who also thanks IFRS (Federal Institute of Education, Science and Technology of Rio Grande do Sul) for the financial support.

\section{Supplementary Material}

Copies of the HRMS spectra of the mechanistic studies and copies of ${ }^{1} \mathrm{H}$ and ${ }^{13} \mathrm{C}$ NMR spectra of the coumarins 3a-0 are provided in the Supplementary Material in the online version of the text.

\section{References}

1. Sarker, S. D.; Nahar, L. Progress in the Chemistry of Naturally Occurring Coumarins; 2017; Vol. 106. https://doi.org/10.1007/978-3-319-59542-9 3

2. Lončarić, M.; Gašo-Sokač, D.; Jokić, S.; Molnar, M. Biomolecules 2020, 10 (1), 151. https://doi.org/10.3390/biom10010151

3. Gaudino, E. C.; Tagliapietra, S.; Martina, K.; Palmisano, G.; Cravotto, G. RSC Adv. 2016, 6 (52), 4639446405. https://doi.org/10.1039/C6RA07071J

4. Sandhu, S.; Bansal, Y.; Silakari, O.; Bansal, G. Bioorganic Med. Chem. 2014, 22 (15), 3806-3814. https://doi.org/10.1016/j.bmc.2014.05.032

5. Smyth, T.; Ramachandran, V. N.; Smyth, W. F. Int. J. Antimicrob. Agents 2009, 33 (5), 421-426. https://doi.org/10.1016/j.ijantimicag.2008.10.022

6. Gonçalves, G. A.; Spillere, A. R.; das Neves, G. M.; Kagami, L. P.; von Poser, G. L.; Canto, R. F. S.; Eifler-Lima, V. L. Eur. J. Med. Chem. 2020, 203. https://doi.org/10.1016/j.ejmech.2020.112514

7. Torres, F.; Brucker, N.; Andrade, S.; Kawano, D.; Garcia, S.; Poser, G.; Eifler-Lima, V. Curr. Top. Med. Chem. 2014, 14 (22), 2600-2623. https://doi.org/10.2174/1568026614666141203144551

8. Singh, H.; Singh, J. V.; Bhagat, K.; Gulati, H. K.; Sanduja, M.; Kumar, N.; Kinarivala, N.; Sharma, S. Bioorganic Med. Chem. 2019, 27 (16), 3477-3510.

https://doi.org/10.1016/i.bmc.2019.06.033

9. Hassan, M. Z.; Osman, H.; Ali, M. A.; Ahsan, M. J. Eur. J. Med. Chem. 2016, 123, 236-255. https://doi.org/10.1016/i.ejmech.2016.07.056

10. Thakur, A.; Singla, R.; Jaitak, V. Eur. J. Med. Chem. 2015, 101, 476-495. 
https://doi.org/10.1016/i.ejmech.2015.07.010

11. Akkol, E. K.; Genç, Y.; Karpuz, B.; Sobarzo-Sánchez, E.; Capasso, R. Cancers (Basel). 2020, 12 (7), 1-25. https://doi.org/10.3390/cancers12071959

12. Dandriyal, J.; Singla, R.; Kumar, M.; Jaitak, V. Eur. J. Med. Chem. 2016, 119, 141-168. https://doi.org/10.1016/i.ejmech.2016.03.087

13. Yu, T.; Zhu, Z.; Bao, Y.; Zhao, Y.; Liu, X.; Zhang, H. Dye. Pigment. 2017, 147, 260-269. https://doi.org/10.1016/j.dyepig.2017.08.017

14. Kumar, A.; Baccoli, R.; Fais, A.; Cincotti, A.; Pilia, L.; Gatto, G. Appl. Sci. 2019, 10 (1), 144. https://doi.org/10.3390/app10010144

15. von Pechmann, H.; Duisberg, C. Berichte der Dtsch. Chem. Gesellschaft 1883, 16 (2), 2119-2128. https://doi.org/10.1002/cber.188301602117

16. Heravi, M. M.; Khaghaninejad, S.; Mostofi, M. Pechmann Reaction in the Synthesis of Coumarin Derivatives. In Advances in Heterocyclic Chemistry; Katritzky, A. R., Ed.; Academic Press, 2014; 112, pp 150 .

https://doi.org/10.1016/B978-0-12-800171-4.00001-9

17. Frère, S.; Thiéry, V.; Besson, T. Tetrahedron Lett. 2001, 42 (15), 2791-2794. https://doi.org/10.1016/S0040-4039(01)00295-7

18. Li, S.; Qi, X.; Huang, B. Catal. Today 2016, 276, 139-144. https://doi.org/10.1016/j.cattod.2015.12.027

19. Zareyee, D.; Serehneh, M. J. Mol. Catal. A Chem. 2014, 391 (1), 88-91. https://doi.org/10.1016/j.molcata.2014.04.013

20. Tyagi, B.; Mishra, M. K.; Jasra, R. V. J. Mol. Catal. A Chem. 2007, 276 (1-2), 47-56. https://doi.org/10.1016/i.molcata.2007.06.003

21. Khaligh, N. G. Catal. Sci. Technol. 2012, 2 (8), 1633. https://doi.org/10.1039/c2cy20196h

22. Bose, D. S.; Rudradas, A. P.; Babu, M. H. Tetrahedron Lett. 2002, 43 (50), 9195-9197. https://doi.org/10.1016/S0040-4039(02)02266-9

23. Spillane, W.; Malaubier, J. B. Chem. Rev. 2014, 114 (4), 2507-2586. https://doi.org/10.1021/cr400230c

24. Heravi, M.; Baghernejad, B.; Oskooie, H. Curr. Org. Chem. 2009, 13 (10), 1002-1014. https://doi.org/10.2174/138527209788680790

25. D’Oca, M. G. M.; Soares, R. M.; de Moura, R. R.; Granjão, V. F. Fuel 2012, 97, 884-886. https://doi.org/10.1016/i.fuel.2012.02.038

26. Chen, W.; Qin, S.; Jin, J. Synth. Commun. 2007, 37 (1), 47-52. https://doi.org/10.1080/00397910600977632

27. Rosa, C. H.; Peixoto, M. L. B.; Rosa, G. R.; Godoi, B.; Galetto, F. Z.; D’Oca, M. G. M.; Godoi, M. Tetrahedron Lett. 2017, 58 (39), 3777-3781.

https://doi.org/10.1016/j.tetlet.2017.08.051

28. An, L.-T.; Zou, J.-P.; Zhang, L.-L.; Zhang, Y. Tetrahedron Lett. 2007, 48 (24), 4297-4300. https://doi.org/10.1016/j.tetlet.2007.04.011

29. Singh, P.; Singh, D.; Samant, S. Synlett 2004, 2004 (11), 1909-1912. https://doi.org/10.1055/s-2004-830858

30. Yasohara, Y.; Kizaki, N.; Hasegawa, J.; Wada, M.; Kataoka, M.; Shimizu, S. Tetrahedron Asymmetry 2001,12 (12), 1713-1718. 
https://doi.org/10.1016/S0957-4166(01)00279-8

31. Ye, X.-W.; Zheng, Y.-C.; Duan, Y.-C.; Wang, M.-M.; Yu, B.; Ren, J.-L.; Ma, J.-L.; Zhang, E.; Liu, H.-M. Med. Chem. Commun. 2014, 5 (5), 650-654.

https://doi.org/10.1039/C4MD00031E

32. Khanapurmath, N.; Prabhu, M. D.; Tonannavar, J.; Tonannavar, J.; Kulkarni, M. V. J. Mol. Liq. 2020, 314, 113620.

https://doi.org/10.1016/j.molliq.2020.113620

33. Robertson, A.; Waters, R. B.; Jones, E. T. J. Chem. Soc. 1932, 1681.

https://doi.org/10.1039/jr9320001681

34. Ahi, B. Y. S. Z.; Desai, A. D. R. D.; May, R. Proc. Indian Acad. Sci. 1937, 6 (1), 6-11.

35. Daru, J.; Stirling, A. J. Org. Chem. 2011, 76 (21), 8749-8755.

https://doi.org/10.1021/jo201439u

36. Tyndall, S.; Wong, K. F.; Vanalstine-Parris, M. A. J. Org. Chem. 2015, 80 (18), 8951-8953. https://doi.org/10.1021/acs.joc.5b01802

37. El-Dafrawy, S. M.; Hassan, S. M.; Farag, M. J. Mater. Res. Technol. 2020, 9 (1), 13-21. https://doi.org/10.1016/j.jmrt.2019.09.063

38. Bahramnezhad, B.; Ghazanfari, D.; Sheikhhosseini, E.; Akhgar, M. R.; Ahmadi, S. A. J. Heterocycl. Chem. 2020, 57 (1), 173-181.

https://doi.org/10.1002/jhet.3763

39. Ye, X. W.; Zheng, Y. C.; Duan, Y. C.; Wang, M. M.; Yu, B.; Ren, J. L.; Ma, J. L.; Zhang, E.; Liu, H. M. Medchemcomm 2014, 5 (5), 650-654. https://doi.org/10.1002/ihet.3763

40. Abbasi, Z.; Rezayati, S.; Bagheri, M.; Hajinasiri, R. Chinese Chem. Lett. 2017, 28 (1), 75-82. https://doi.org/10.1016/j.cclet.2016.06.022

41. Bistrović, A.; Stipaničev, N.; Opačak-Bernardi, T.; Jukić, M.; Martinez, S.; Glavaš-Obrovac, L.; Raić-Malić, S. New J. Chem. 2017, 41 (15), 7531-7543. https://doi.org/10.1039/C7NJ01469D

42. Katkevičs, M.; Kontijevskis, A.; Mutule, I.; Sūna, E. Chem. Heterocycl. Compd. 2007, 43 (2), $151-159$. https://doi.org/10.1007/s10593-007-0025-x 